\title{
A Visual Call to Arms against the "Caracature [sic] of My Own Face:" From Fugitive Slave to Fugitive Image in Frederick Douglass's Theory of Portraiture
}

\section{CELESTE-MARIE BERNIER}

Self-emancipated author, activist and philosopher turned art historian, Frederick Douglass spent a lifetime visualizing back to a white dominant schema intent on trading in racist grotesques of socially determinist and politically reductive contortions of black bodies and souls. Across his photographic and fine-art portraits, he endorsed a revisionist aesthetic theory and carved out an alternative iconographic space within which to expose, debunk and demythologize the racist claim that "Negroes look all like." Douglass's visual aesthetic took as its starting point the formal, political and ideological importance of representing black subjects as psychologically complex individuals rather than as generic types. At the heart of Douglass's theory of portraiture was his conviction that all likenesses of African American subjects must do justice to "the face of the fugitive slave" by conveying the "inner" via the "outer man," and thereby privilege emotional depth rather than physical surface in order to extrapolate a full gamut of lived realities otherwise annihilated out of existence. Douglass worked extensively with the signifying possibilities of his own physiognomy as a representative test case by which to bear witness to the interior complexities of black subjects missing from, or remaining fugitives at large within, white artists' surface-only renderings.

Self-emancipated author, activist and philosopher Frederick Douglass was not only a household name but a household image throughout the nineteenth century. As revealed by his staged appearances within an array of photographs, fine-art portraits, engravings, lithographs, paintings and sculpture - no less than his outpouring of autobiographies, essays, speeches, political manifestos,

Department of American and Canadian Studies, University of Nottingham. Email: celeste-marie.bernier@nottingham.ac.uk. This article is written in heartfelt acknowledgement of the inspirational guidance and expertise of world-leading Frederick Douglass scholars Bill E. Lawson and Fionnghuala Sweeney. While the errors are all mine, I would like to signal my profound gratitude to the anonymous reviewer of the manuscript and to Bevan Sewell for their expert editorial guidance that has proved of fundamental importance in finalizing this article. 
art-historical treatises, poetry and a novella - Douglass was at war against the intellectual, cultural, social, moral, political and artistic damage resulting from white racist attempts to commodify and objectify both his own physicality and the corporeal realities of enslaved and self-emancipated black women, children and men. ${ }^{\mathrm{I}}$ For Douglass, these forces were at work not only within the official archives which he recategorized as "chattel records" - such as plantation ledgers, bills of sale, legal decrees and runaway-slave advertisements - but, and even more revealingly, within white mainstream fine art and popular culture. ${ }^{2}$ In his writing, he remained immovable in his conviction that "Negroes can never have impartial portraits, at the hands of white artists." Denouncing the biases at work within white representations of black subjects, he declared, "It seems to us next to impossible for white men to take likenesses of black men, without most grossly exaggerating their distinctive features." For Douglass, the "reason is obvious": "Artists, like all other white persons, have

' For a detailed discussion of Douglass's strategies of self-representation across his oratorical, writerly and visual bodies of work see my forthcoming literary biography, Living Parchments: Artistry and Authorship in the Life and Works of Frederick Douglass (New Haven: Yale University Press, 2018). For an in-depth examination of Douglass's strategies of self-fashioning within photographic and fine-art portraiture, as well as within his writings and speeches, see my following articles and books: "From Fugitive Slave to Fugitive Abolitionist: The Oratory of Frederick Douglass and the Emerging Heroic Slave Tradition," Atlantic Studies, 3, 2 (2006), 201-24; “"The Face of a Fugitive Slave': Representing and Reimagining Frederick Douglass in Popular Illustrations, Fine Art Portraiture and Daguerreotypes," in Magnus Brechkten, ed., Political Memory (Göttingen: Vandenhoeck \& Ruprecht, 20 I2), I I-33; “A 'Typical Negro' or a 'Work of Art'? The 'Inner' via the 'Outer Man' in Frederick Douglass's Manuscripts and Daguerreotypes," Slavery and Abolition, 33, 2 (2012), special issue ed. Fionnghuala Sweeney, 287-303; “A 'Work of Art:' Frederick Douglass's 'Living Parchments' and 'Chattel Records," Chapter 5 of my book Characters of Blood: Black Heroism in the Transatlantic Imagination (Charlottesville: University of Virginia Press, 201 2); 25 1-98; "A Life in Art: The Case of Frederick Douglass," in African American Review, special issue, Imaging Frederick Douglass, ed. Celeste-Marie Bernier and Bill E. Lawson (forthcoming 2016). For access to a full examination of Douglass's photographic archive as excavated and theorized by myself, John Stauffer and Zoe Trodd, see the introductory essay, in-depth captions, essay transcripts and catalogue raisonné of all known Douglass images in CelesteMarie Bernier, John Stauffer and Zoe Trodd, eds., Picturing Frederick Douglass, Foreword by Henry Louis Gates , Jr. (New York: W. W. Norton \& Co., 2015).

${ }^{2}$ Frederick Douglass, The Heroic Slave, in Julia Griffiths, ed., Autographs for Freedom (Boston: John P. Jewett, I 853), I 74-239, I75. For further information concerning his own writings on the picture-making process see Douglass, "Pictures and Progress" (3 Dec. I 86I), in The Frederick Douglass Papers, Series One: Speeches, Debates, and Interviews, ed. John W. Blassingame, Volume III (New Haven: Yale University Press, 1979), 452-73; "Lecture on Pictures [title varies]," n.d., "Series: Speech, Article, and Book File - A: Frederick Douglass, Dated." All are available in the Frederick Douglass Papers at the Library of Congress: http://memory.loc.gov/ammem/doughtml/doughome.html, accessed Jan. 20 I 4. 
adopted a theory respecting the distinctive features of Negro physiognomy. We have heard many white persons say, that 'Negroes look all like."'3

The vast majority of white-generated imagery on offer within elite and popular culture throughout the nineteenth century confirmed Douglass in his belief that white artists "associate with the Negro face, high cheek bones, distended nostril, depressed nose, thick lips, and retreating foreheads." Warring against the collateral damage produced by such an iconographic stranglehold, Douglass was under no illusion that " $\mathrm{t}]$ his theory impressed strongly upon the mind of an artist exercises a powerful influence over his pencil, and very naturally leads him to distort and exaggerate those peculiarities, even when they scarcely exist in the original." 4 Writing of the portraits of black historical figures included in white-abolitionist-turned-historian Wilson Armistead's volume $A$ Tribute for the Negro, published in Manchester and London in the UK in 1848 , as a test case regarding widespread tendencies to "distort and exaggerate" black physiognomies, Douglass fused his opposition to its textual premise - "Here is a large volume, made up of extracts from the sayings of authors - travellers, missionaries, sea-captains, doctors, lawyers, and philosophers, - and all these to prove, what? Simply, that the present reviewer is a member of the human family" - with an outright rejection of the authorturned-artist's pretensions towards physical accuracy in his engravings of black subjects. " "The superior portraits referred to in the title page, raise expectations not to be gratified on looking into the book - for with but two exceptions they are of the commonest sort," Douglass writes, explaining of his own likeness in particular, "That of Frederick Douglass, we shall leave others to criticise, begging only to remark that, it has a much more kindly and amiable expression, than is generally thought to characterize the face of the fugitive slave" (Figure I). ${ }^{6}$

As I argue in this article, even a very brief comparison of only a handful of Douglass's photographic and frontispiece portraits with Armistead's engraving immediately confirms that nothing could be further from his oversimplified imagining of a dandified, luxuriously coiffured and jauntily smiling likeness than Douglass's poignantly emotive dramatization of the "face of the fugitive slave" in the uniformly haunting, yet unequivocally defiant, face of Frederick Douglass that comes to life within his visual archive over the decades. In powerful contrast to his reductive appearances, not only within

3 Frederick Douglass, "A Tribute for the Negro" (1849), repr. in The Life and Writings of Frederick Douglass, ed. Philip S. Foner, Volume I (New York: International Publishers, I950), 379-84, 380, emphasis mine.

4 Ibid., emphasis mine.

5 Ibid., 382.

${ }^{6}$ Ibid., 379, 379-80. 


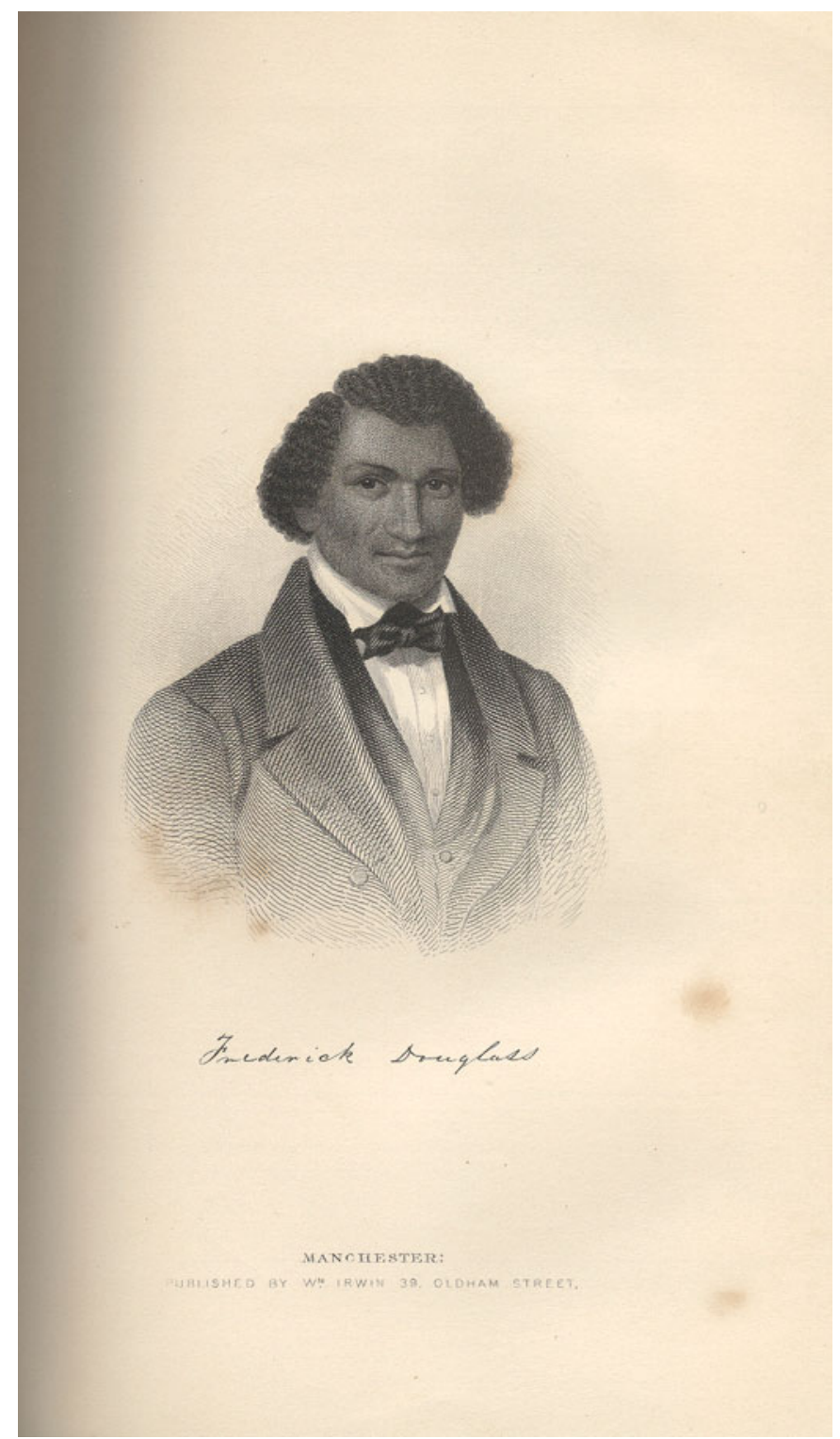

FIgURE I. Anon., "Frederick Douglass, a Fugitive Slave," in Wilson Armistead, $A$ Tribute for the Negro: Being a Vindication of the Moral, Intellectual, and Religious Capabilities of the Coloured Portion of Mankind; with Particular Reference to the African Race (Manchester: William Irwin, I 848), 456. Courtesy of Documenting the American South, University of North Carolina.

Armistead's one-dimensional engraving of the "commonest sort" but in an array of fine-art and popular representations that similarly traded in white supremacist - for which read one-dimensional and fixed-fantasies of his 
face and body, Douglass generated a radically revisionist series of portraits in which he cultivated a self-consciously dramatic and psychologically charged for which read antireductive and fugitive - use of his own physical expression. Deeply opposed to the buying and selling of white racist caricatures of his own image and of enslaved and free black subjects within an anti- no less than proslavery imaginary, he developed an alternative theory of portraiture which was to undergird his lifelong practice as he choreographed an extensive body of photographic and fine-art images to produce "superior portraits" over which he exerted control as a powerful art-historical and cultural corrective. Throughout his lifetime, and as I trace here, he sought to convey the visual antithesis of a "kindly and amiable expression," not only in his daguerreotypes taken in the 1840 s and I 850 s, but across the ambrotypes, cartes de visite, albumen prints and cabinet cards, as well as the fine-art portraits and frontispieces which he himself commissioned and which circulated right up until his death in I 895. Artfully turning on its head a white visual schema trading in racist grotesques of a socially determinist and politically reductive contortion of black faces and bodies, Douglass endorsed a revisionist aesthetic theory and carved out an alternative iconographic space by creating multilayered portraits in which he sought to expose, debunk and demythologize the illusory foundations of the dismissive claim that "Negroes look all like." Warring against a white racist notion that one size, shape and form fit all regarding black humanity, Douglass's visual aesthetic took as its starting point the formal, political and ideological importance of representing black subjects as psychologically complex individuals rather than as generic types, flattened icons or caricatured nonentities. At the heart of Douglass's theory of portraiture was his conviction that all likenesses of African American subjects, enslaved and free, must do justice to "the face of the fugitive slave" by conveying the "inner" via the "outer man" and thereby work with emotional depth rather than physical surface in order to extrapolate a full gamut of lived realities otherwise annihilated out of existence. 7 Across his visual archive, Douglass worked extensively with the signifying possibilities of his own physiognomy to encapsulate a gamut of facial expressions, and as a representative test case by which to bear witness to the interior complexities of black subjects missing from, or remaining fugitives at large within, white artists' surfaceonly renderings. ${ }^{8}$

Betraying a lifelong commitment to defying white voyeuristic assumptions while inspiring empathetic engagement among his audiences, Douglass sought

7 Douglass, "Pictures and Progress," 455.

8 See Bernier, Stauffer and Trodd, Picturing Frederick Douglass, for a catalogue raisonné of Douglass's photographic archive. 
to dramatize the "face of the fugitive slave" by relying on an emotively charged yet masked use of his own facial expression in order to extrapolate an array of psychological, imaginative and existential realities otherwise iconographically off-limits within white mainstream imagery. Interpreting the obstacles besetting any accurate delineation of his own face and body as a revealing touchstone for the situation confronting enslaved and self-emancipated black women and men more generally, Douglass's determination to exert control over his appearance in his frontispiece portraits as well as his photographic images worked in conjunction with his increasing adoption of the roles of art historian and theorist of the social, political and artistic values of portraiture as a quintessential declaration of self-emancipation. As I show here, a discussion not only of white racist misrepresentations of Douglass's face and body alongside a sample of his photographic images, but also of the frontispiece portraits and the interior images included within Douglass's ante- and postbellum literary autobiographies - Narrative of the Life of Frederick Douglass (i 845), My Bondage and My Freedom (1855) and Life and Times of Frederick Douglass ( $188 \mathrm{I}$ )-makes it possible to shed further light on his cultivation of a semantic slippage between public and private, representative and individual, archetypal and fallible, and spiritual and corporeal states of existence as per his construction of a revisionist reimaging not only of fugitive rather than fixed images, but also of fugitive rather than fixed constructions of selfhood.9 Working to reveal intellectual, imaginative and psychological, over and above physical, states of existence across his visual as well as his textual archive, Douglass engaged in self-reflexive strategies of self-masking, performance, staging and stylization. His was an ongoing war against a white racist scopic terrain as characterized, on the one hand, by an entrenched determination to invizibilise black bodies according to dehumanizing caricatures and stock archetypes, and, on the other, by a commitment to erasing black subjectivities entirely in a repositioning of black bodies solely as objects of exchange within a system of slavery. For Douglass, the nefarious practices endorsed by slaveholding whites, and according to which black bodies were exposed to abusive rituals of physical inspection, examination and valuation, existed on a continuum, at least in visual terms, with a white abolitionist determination to trade only in authenticated subjects and verifiable witnesses. In both cases black bodies and souls were appropriated, commodified and

9 Frederick Douglass, Narrative of the Life of Frederick Douglass (Boston: Anti-slavery Office, I 845); Douglass, My Bondage and My Freedom (New York: Miller, Orton and Mulligan, I 855); Douglass, Life and Times of Frederick Douglass (Hartford, CT: Park Publishing Company, i $88 \mathrm{I}$ ). 
objectified for white financial or moral gain, with powerful aesthetic as well as political and ideological consequences.

\section{TRACING THE PHYSICAL AND PSYCHOLOGICAL CONTOURS OF THE "FACE OF THE FUGITIVE SLAVE"}

As Douglass's commitment to shifting strategies of self-representation reveal, his reimaging of his own physiognomy as belonging to that of the archetypal "fugitive slave" across his visual archive is made possible not solely due to his legal status. If interpreted only on these grounds, Douglass's period as a legally enslaved man turned self-emancipated fugitive has limited applicability by referring to a very brief time frame during his long lifetime: the eight years between his escape from Baltimore in 1838 and the purchase of his freedom in 1846 by white British abolitionist Anna Richardson, from his owner, Hugh Auld, who secured Douglass's sale by setting a price on his flesh and blood: as he stipulated, "I will Take i 50 £ Sterling for the manumission $\left[\right.$ sic] of my slave Frederick Bailey, alias, Douglass." ${ }^{\circ}$ Extending way beyond this limited period and into his life as a legally liberated individual, Douglass interpreted his status as a fugitive slave - and by extension his determination to do justice to the "face of the fugitive slave" - as far from over following his receipt of his manumission papers, as his sense of a fugitive selfhood continued to dominate his physical and psychological landscape, if not in legal then in existential, emotional, imaginative, political and philosophical terms. To the fore within Douglass's visual and textual archive in general, and in particular across his repeated, self-conscious stagings as "the face of the fugitive slave" in his portraits, is his lifelong conviction regarding the extent to which an enslaved past continued to dominate a freed present for self-liberated African Americans. For Douglass, therefore, the category of the "fugitive slave" provided a powerful framework through which to represent an unresolved state of existence not only for himself but for self-emancipated women, men and children more generally. Across his bodies of work, he worked to expose the extent to which white abolitionist endorsements of a seemingly clear-cut trajectory characterizing an individual's journey from slavery to freedom as one of no return was to remain an illusory fantasy for countless numbers of African American subjects battling discriminatory forces following their acts of self-emancipation. ${ }^{11}$

10 Hugh Auld, "Letter to Anna Richardson," 6 Oct. I 846, full transcript available online at www.gilderlehrman.org/sites/default/files/inline-pdfs/T-07484.04.pdf.

${ }^{11}$ See Bernier, Characters of Blood, $25 \mathrm{I} \mathrm{ff}$. 
Speaking candidly in a speech titled "American Slavery's Disgrace," delivered in Sheffield towards the end of his first transatlantic speaking tour in the UK in 1847 and a year prior to the publication of Armistead's volume, Douglass shed further light on the political principles undergirding the strategies of self-imaging at work within his visual archive. Sharing with his audiences his heightening sense of moral and social outrage at the atrocities of slavery, he emphasized, "this feeling necessarily produced dissatisfaction ... constantly manifesting itself in the looks of a slave." As the anonymous reporter recording his speech summarizes, Douglass explained that, he "had been punished and beaten more for his looks than for anything else - for looking dissatisfied because he felt dissatisfied - for feeling and looking as he felt at the wrongs heaped upon him." ${ }_{12}$ In powerful visual declarations of independence, he dispensed with a "kindly and amiable expression" not only within the rhetoric of his speeches but also within the self-stylization of his photographic and fine-art images in order to begin to do justice to the "face of the fugitive slave" by conveying the "dissatisfaction" expressed in the "looks of a slave." Across his portraits he rendered his exposure to pre- and postemancipation suffering clear-cut by attesting to the dystopian reality that, "beaten" for his "looks" as a slave, he was no less vulnerable to physical assault for his "looks" as a freeman. At the same time that his performative reenactment of his dissident "looks as a slave" is revealing regarding the political and cultural weight of his own life lived during slavery, his strategies of self-imaging testify to an unresolved and traumatized sense of selfhood following his self-emancipation. Bearing witness to his sense not only of individual but also of collective suffering on a mass scale, in the same way that Douglass relied on his series of written autobiographies as a platform on which to protest against the atrocities experienced by the "American slave" more generally, across his visual archive he manipulated his physiognomy in a bid to encapsulate not only his individual likeness but also the archetypal "face of the fugitive slave" as he sought to speak for-or image for-the vast number of unrepresented lives. Working to signify beyond the parameters of his own life story, he transformed his sense of a private and fallible selfhood into a public and mythological touchstone by generating a body of self-representations that would ensure his circulation as the ur-image or quintessentially representative icon powerfully suited to encapsulating the plight of untold, and as yet unimaged, millions. For viewers of his portraits, the

12 See Frederick Douglass, "American Slavery's Disgrace: An Address Delivered in Sheffield England on 25 March I 847," in John W. Blassingame, ed., The Frederick Douglass Papers, Series One: Speeches, Debates, and Interviews, Volume II (New Haven: Yale University Press, 1979), го. 
revelation that he was "beaten more for his looks than for anything else" during his history of enslavement lays bare the protest aesthetic integral to his visual archive. According to Douglass's artistic and political vision, his repeated determination to restage the "look of a slave" by "feeling and looking as he felt" after his self-emancipation bears witness to the extent to which his deathless life as an enslaved man bled into the living death that was a black individual's life in freedom.

Confronted with the "spirit of slavery" that lived on in an "inveterate prejudice against color" which sought to objectify and commodify black women and men, for Douglass, the category of the "fugitive slave" - as broadly defined provided a compelling lens through which to shed light on the realities of an existence that was neither enslaved nor free. ${ }^{13}$ As revealed within his visual archive, Douglass sought to transform his exposure to an existential no-place in an ongoing physical and psychological state of fugitivity in white US mainstream society into the catalyst for developing self-reflexive strategies for reimaging and reimagining black selfhood. As per Douglass's strategies of self-representation, it was his experimental forays - as motivated by a determination to do justice to his status as the physical and spiritual embodiment of the fugitive slave in literary, oratorical and, above all, visual terms - that provided a counter to white mainstream attempts to appropriate and fix black identities according to racist formulas of misperception and distortion. Painfully and personally aware of the social, political, moral and cultural death that was black freedom in the ante- and postbellum United States, Douglass commissioned photographic and frontispiece portraits in which he fought to image the "face of the fugitive slave" in order to galvanize black resistance to white racist acts of disenfranchisement and dispossession that continued to persecute the lives of liberated black subjects.

Cultivating an array of personae during his lifetime, as there was not one but many Frederick Douglasses, at the same time that he repeatedly celebrated his moments of personal epiphany in acts of self-liberation by declaring, "however long I might remain a slave in form, the day had passed forever when I could be a slave in fact," years and even decades after he had ceased to be a fugitive slave in "fact," Douglass continued to foreground his status as a fugitive slave in "form." ${ }^{14}$ First and foremost across his photographic representations, portrait frontispieces and commissioned fine-art portraits, he displayed his commitment to translating the liminal position of the "fugitive slave" into the liberatory potential of the fugitive image. Self-reflexively interrogating formal and generic boundaries to create an experimental visual as well as written

${ }_{13}$ Douglass, Life and Times of Frederick Douglass, 277, 303.

${ }^{14}$ Douglass, Narrative of the Life, 73. 
archive, for Douglass it was the art no less than the act of self-imaging and selfimagining across his visual archive that remained integral to his determination to develop a theory of portraiture by which to emancipate the faces and bodies not only of himself but also of black subjects more generally. In his engagement with and active intervention in the processes of black representation within photographic and fine-art portraiture, he challenged white notions that legal emancipation alone conferred freedom. Working to do justice to the "face of the fugitive slave" across his bodies of work, Douglass relied on artistic strategies of self-imaging in order to lay claim to the black subject's right to appear not in fixed visual representations trading in racist types - and as on offer in cartoons, scientific diagrams, medical drawings and political iconography, among much more - but in fugitive images celebrating black individualism and humanity which were defined by the right to freedom of physiognomic expression in specifically commissioned photographs, frontispieces and fineart portraits. Signalling his rejection of white imprisoning frameworks of black representation, Douglass's determination to translate the archetypal figure of the fugitive slave into a liberated and liberating fugitive image was to remain a defining feature of his aesthetic project and of his lifelong quest to wrest control over African American representations across nineteenthcentury visual and print cultures.

Recognizing the importance of Angela Rosenthal and Agnes Lugo-Ortiz's conviction that "slave portraiture has remained a practically uncharted territory," as I argue, an in-depth examination of Douglass's theories of self-imagining confirms the extent to which his strategies are consistent with a genre that can be more specifically defined as "fugitive slave portraiture." Is In practical terms, and as close readings of individual works reveal, the more general designation "slave portraiture" presents very real interpretative difficulties on the ground that the vast majority of black historical figures - including not only Douglass himself but also Phillis Wheatley, Henry Box Brown, Solomon Northup, Jarena Lee, Elizabeth Keckley, Harriet Tubman, Henry Bibb, Moses Roper and William Wells Brown, among thousands of others were, at the moment of having their likenesses made, either self-emancipated individuals or subjects occupying the theoretical, aesthetic and politically liminal category of the "fugitive slave." In this regard, Marcia Pointon's generalization that "slave portraits may be more about process and contingency than about absolute conditions" works powerfully with excavating a history of "fugitive slave portraiture," as endorsed by Douglass in particular but as

is Agnes Lugo-Ortiz and Angela Rosenthal, "Introduction," in Lugo-Ortiz and Rosenthal, eds., Slave Portraiture in the Atlantic World (Cambridge: Cambridge University Press, 2013), I-40, I 4. 
expressed by self-liberated women and men more generally, by providing a framework in which to do justice to his lifelong conviction that slavery and freedom remained relative rather than absolute physical and psychological states of existence. ${ }^{16}$ In this regard, Marcus Wood's illuminating emphasis that the "pictures in slave narratives written by blacks often resist, or recast, established illustrational and graphic codes for the depiction of slave escape" can be adapted to suggest the ways in which formerly enslaved women and men such as Douglass adopted the roles of artist and author in a bid to "resist" and "recast" not only the iconography of "slave escape" but the iconography of "fugitive slave" representation more generally. ${ }^{17}$

Investigation into the self-reflexive practices at work within Douglass's photographic and fine-art self-representations is suggestive regarding the ways in which black subjects were historically engaged in transforming Rosenthal and Lugo-Ortiz's centuries' later lament regarding the "paradoxical presence and erasure of the enslaved subject in portraiture" into a catalyst for imaginative possibilities even at the height of US chattel slavery and in its immediate aftermath. ${ }^{18}$ Working not only to write but also to vizualise black subjects into existence, Douglass and other formerly enslaved and selfemancipated authors and artists endorsed an aesthetics of resistance via strategies of self-staging designed to challenge a long-standing perception that, as David Bindman summarizes, the "terms 'slave' and 'portrait' constitute together an oxymoron, a contradiction in terms." ${ }^{19}$ Working to reject any such "contradiction in terms" by creating shifting rather than fixed and multifarious rather than monolithic reimagings of black identities, formerly enslaved and self-emancipated figures relied upon an accompanying visual apparatus in their published writings by which to shed light not only upon white racist determinations to appropriate enslaved subjectivities but also upon a black revisionist commitment to engage in self-reflexive acts and arts of resistance. In this regard, and as Douglass's visual archive confirms, the category of "fugitive slave portraiture" has the potential to allow viewers to come to grips with the signifying practices at work within their self-fashioning strategies and by which they were intent upon, as Richard J. Powell theorizes, "cutting a figure." 20

${ }^{16}$ Marcia Pointon, "Slavery and the Possibilities of Portraiture," in Lugo-Ortiz and Rosenthal, Slave Portraiture, $4 \mathrm{I}-70,47$.

${ }_{17}$ Marcus Wood, Blind Memory: Visual Representations of Slavery in England and America, 1780-1865 (Manchester: Manchester University Press, 2000), Io0.

${ }^{18}$ Lugo-Ortiz and Rosenthal, "Introduction," 4.

19 David Bindman, "Subjectivity and Slavery in Portraiture: From Courtly to Commercial Societies," in Lugo-Ortiz and Rosenthal, Slave Portraiture, 7 I-88, 75.

${ }^{20}$ See Richard A. Powell, Cutting a Figure: Fashioning Black Portraiture (Chicago: The University of Chicago Press, 2009). 


\section{FUGITIVE PORTRAITS: IN THEORY}

As multilayered, experimental and ambiguous works paradoxically characterized by strategies of narrative explication and withholding, Douglass's portraits betray many points of similarity with the formal strategies at work within his written and oratorical oeuvre. In each case, he was engaged in the search for a new language, visual as well as textual, in which to represent the unrepresentable regarding individual and collective experiences of enslavement and emancipation. Profoundly aware of the commodifying forces at work not only within the legal institution of slavery but as indelibly intertwined within abolitionist discourses and iconography, Douglass was also virulently opposed to his treatment on the anti-slavery podium. "I was generally introduced as a 'chattel' - a 'thing' - a piece of southern 'property', the chairman assuring the audience that it could speak," he denounced, simultaneously satirizing the ongoing injustices of a situation in which "I had the advantage of being a 'brand new fact' - the first one out." ${ }_{21}$ Tellingly, Douglass's declarations of authorial independence by which he repeatedly foregrounded the expressive failures of literary language in a bid to reject the demands of a white audience intent upon gaining no-holds-barred access to his psychological and physical experiences find a corollary in his lifelong determination to engage in artful strategies of self-imaging across his photographic, frontispiece and fine-art portraits. Rejecting white racist reductive reimaginings of his identity as a "chattel," a "thing" or a "brand new fact," Douglass's visual archive betrays his deliberate imaging of a multiplicity of selves that sought to transform the existential no-place - psychically and physically simultaneously half-free and half-slave - of the "fugitive slave" not into a body of proof but into an art-historical as well as a literary first. In stark contrast to the prescriptions besetting a formerly enslaved narrator for whom the pressure was on to supply only an "unvarnished tale" or a "bare narration of facts" in written form, Douglass relished in the creative possibilities for self-representation presented by visual culture. According to his strategies of self-imaging, the signifying force of "[p]ictures, images, and other symbolical representations" derived not from their seemingly factual basis but from their tried and trusted ability to "speak to the imagination." 22

Warring against a white-dominant lens that sought to perpetuate reductive constructions of black identities, the concept of the "fugitive slave," no less than the attempt to encapsulate "the face of the fugitive slave" in portraits

${ }^{21}$ See Frederick Douglass, My Bondage and My Freedom (New York and Auburn: Miller, Orton \& Mulligan, I 855), 360, 361 .

${ }^{22}$ See Douglass, "Lecture on Pictures [title varies]." Also see the forthcoming transcript in Bernier, Stauffer and Trodd, Picturing Frederick Douglass. 
that "speak to the imagination," assumes centre stage within Douglass's lifelong quest to wrest control over his appearances in the visual and textual archive. For Douglass, the concept of the "fugitive slave" was a more liberated and liberating construction than his reductive circulation as a "chattel," "thing" or a "brand new fact" within white abolitionist oratory, or as an exalted specimen, object of trade and archetypal runaway icon within mainstream newspapers and marketing advertisements. As a powerful case in point, Douglass registered his opposition to a description of his physique employed by one white British journalist in particular, who "took occasion to speak of me as a fine young Negro," as he warned transatlantic audiences regarding the reporter's indebtedness to racist terminology by explaining, "that is the mode of advertising in our country a slave for sale." ${ }^{3}$ Correspondingly, Douglass's self-representation as the quintessential "fugitive slave" across his photographic and fine-art archive visualizes back to his repeated circulation not only according to a white slave-trader's bill of sale but also as per the generic schema of the archetypal enslaved runaway advertisement. Decades later, he concedes, "It is true that I was once advertised in a very respectable newspaper under a little figure, bent over and apparently in a hurry, with a pack on his shoulder, going North." ${ }^{24}$ Revealingly, this advertisement has never been found. Rather, as John Blassingame and John McKivigan have shown, a cartoon executed by an anonymous artist and adhering to this description was published in Frank Leslie's Illustrated Newspaper on I 2 November 1859 (Figure 2). ${ }^{25}$ The artist's decision not to represent Douglass according to a generic type - the caption clearly, if disparagingly, identifies the figure as "Fred. Douglass" - does nothing to mitigate his dehumanization in a profoundly offensive illustration that constitutes a non-portrait. Appearing as the visual antithesis of Douglass's shifting construction as the archetypal "fugitive slave," his face and body have been reduced to a caricatured grotesque in which distortions of skin tone and facial features

${ }^{23}$ Frederick Douglass, "American Prejudice against Color: An Address Delivered in Cork, Ireland, October 23, I 845," repr. in The Frederick Douglass Papers, Series One: Speeches, Debates, and Interviews, ed. John W. Blassingame, Volume I (New Haven: Yale University Press, 1979), 66.

${ }^{24}$ Frederick Douglass, "Which Greely Are We Voting For? An Address Delivered in Richmond Virginia on 24 July I 872," repr. in The Frederick Douglass Papers, Series One: Speeches, Debates, and Interviews, eds. John W. Blassingame and John R. McKivigan, Volume IV (New Haven: Yale University Press, 1979), 303.

${ }^{25}$ Ibid. Blassingame and McKivigan's editors' note on the same page confirms that "[a] lthough Douglass seems to be referring to an advertisement published at the time of his escape from slavery in 1838 , such a notice has not yet been uncovered," alluding instead to the fact that "[i]n early November a cartoon appeared in Frank Leslie's Illustrated Newspaper that depicted Douglass, shoes flying from his feet and a traveler's trunk perched on his shoulder, hurriedly fleeing toward Canada." 


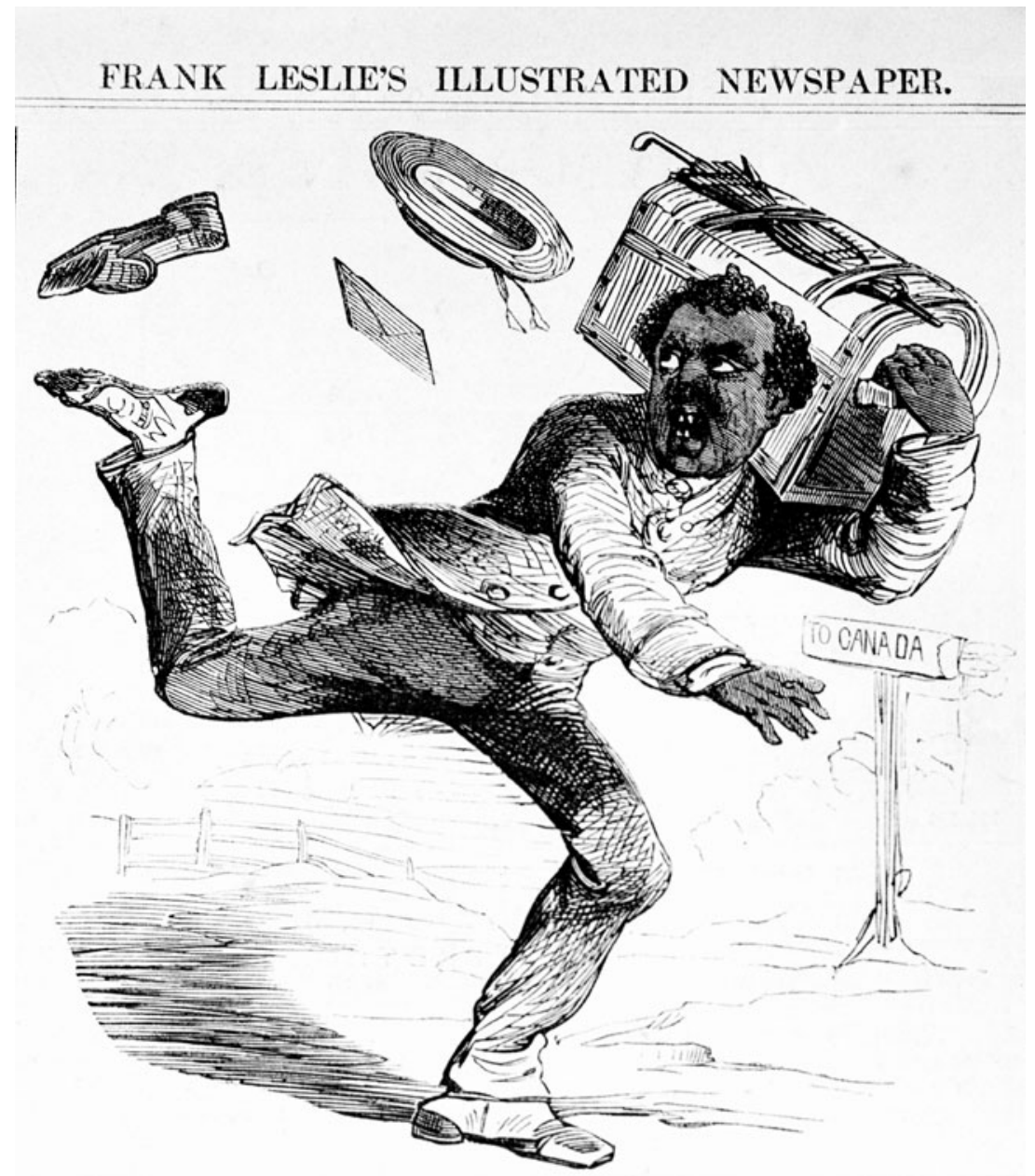

THE WAY IN WHACA FHED. DOCGLASS FIGHTS WISE OF VIHGISIA.

"I have always been more distinguished for running than fighting."-Fred. Douglass' Letter to the Rochester Papers.

Figure 2. Anon., "The Way in Which Fred. Douglass Fights Wise of Virginia," Frank Leslie's Illustrated Newspaper, I 2 November I 859, 382. Courtesy of West Virginia State Archives.

combine with a depiction of dishevelled clothing and diminutive physique to render him unrecognizable. While Douglass's response to his representation in this specific image and other racist cartoons has so far remained impossible to trace, he was categorical in his opposition to generalized reimaginings of "fugitive slaves" as "little bent over figures." Virulent in his protest against the runaway-slave advertisements dominating the mainstream press within the pages of his own newspaper - "Think of a respectable newspaper representing 
the moral sentiment of the most influential part of the community, stringing together, in its long columns, in company with horses, sheep, and swine, the figures of forty human beings, to be disposed of in the same market with the former" - Douglass reserved special ire for the accompanying visual apparatus. As he notes, "To each of the advertisements ... is prefixed the figure of a human being, as if in the act of running." Ensuring the removal of this dehumanizing iconography, he delighted in the fact that "[w]e have no such figures nor prints in our office, to enable us to follow copy," insisting instead, "the reader must supply them for himself." ${ }^{26}$ While Douglass's first preference was for substituting white racist caricatures with individualized and even self-consciously mythologized black portraits, if such representations remained iconographically unavailable, he purposefully removed all trace of derogatory imagery in order to inspire audiences to transgress racial divides and engage in empathetic acts of imaginative identification.

As his life and works demonstrate, Douglass was radically opposed to the buying and selling of black women, children and men, not least as objects of trade upon the auction block, as tools of propaganda upon the abolitionist podium, as spectacularized icons of display on the minstrelsy stage, as specimens of anthropological investigation, as bestialized racial types according to the visual schema of scientific racism, and, more especially and yet little discussed, as stock caricatures according to white European and European American art-historical traditions. Inscribing concealment rather than revelation into his visual repertoire, he preferred to circulate his own face and body in fugitive rather than fixed portraits as he laid down the gauntlet to the commodified circulation of enslaved subjects within atomized lists of auction advertisements. At the same time, he rejected the status of enslaved subjects as authenticated proofs within anti-slavery broadsides and protested against their invisibilization within the formal constraints of the slave narrative genre, a literary form which ran the risk of equating personal histories to bodies of evidence. Refusing white audiences voyeuristic access to the baring of his soul and his body, and setting himself defiantly at odds with white abolitionist intentions of "taking me" as a "text" or even as an image, Douglass's cultivation of the "face of the fugitive slave" in his photographs and fine-art portraits resulted in what I designate here a series of fugitive images in which his face

${ }^{26}$ Frederick Douglass, "Oh Liberty! What Deeds Are Done in Thy Name!", North Star, 22 Feb. I 850, 2. Any scholarly investigation into Douglass's relationship with white mainstream iconography must acknowledge the seminal importance of Sarah Blackwood's pioneering research in which she uncovered this editorial in her article "Fugitive Obscura: Runaway Slave Portraiture and Early Photographic Technology," American Literature, 8I, I (March 2009), 93-I25. 
and body were no longer caricatured or objectified. Displaying full control, he constructed an alternative visual archive in which his physiognomic expression was neither self-evident nor exaggerated but remained ambiguous and emotively off-limits while he adopted an erect and stationary - rather than bent over or running - posture to ensure that his physique was not grotesquely rendered. ${ }^{27}$ Working with an array of signifying strategies, he sought to produce a body of portraits whose formal properties and thematic effects would act as the visual antithesis of an advertisement or cartoon by instead succeeding in resonating with the metaphorical and symbolic possibilities of a "work of art." ${ }^{28}$ Neither dehumanized grotesque, generic archetype nor body of proof as per his circulation with white racist cartoons and anti-slavery propaganda no less than slavery's marketing apparatus, Douglass's photographs and fine-art portraits "speak to the imagination" by relying on alternative strategies of self-representation. Across his visual archive, he reimagined the "face of the fugitive slave" by relying on a pained - and sometimes even tortured - yet ultimately unfathomable facial expression in profoundly aestheticized and stylized pictures within which he sought to reinforce heightened associations between his face and body and classical sculpture as well as fine-art portraiture. For Douglass, the emancipatory potential of portraiture could not be realized via rigorous adherence to a seemingly meticulous verisimilitude because any such preoccupation ran the risk of replicating white racist strategies of attempting to fix black subjects as bodies of evidence. In this regard, his portraits generate more questions than answers as his self-consciously traumatized expression gestures towards but does not fully expose the individual lines on his face while he consistently refused to provide audiences with visual access to his scarred back as he thereby fought to reject his status as a living proof of slavery's atrocities. For Douglass, the necessity was to pioneer a new form of visual representation characterized by the circulation of black subjects within fugitive - for which read complex - rather than fixed - for which read selfevident - images in which they retained authority as absent presences and present absences within white official records as well as mainstream art-historical representations.

Surviving as a dominant preoccupation throughout his "life as a freeman," Douglass's search for a new visual as well as literary and oratorical language within which to defy white racist attempts to "distort and exaggerate" the "life of a slave" operated as the catalyst to his determination to transform

27 Douglass confides in My Bondage and My Freedom regarding the fact that William Lloyd Garrison betrayed a repeated interest in "taking me as his text" in his speeches. See $M y$ Bondage and My Freedom, 358.

${ }^{28}$ Frederick Douglass, "Pictures and Progress" (I 861), repr. in The Frederick Douglass Papers, Series One, Volume III, 460. 
images of himself and of black women, children and men into "works of art." 29 For Douglass, the insertion of black subjects into the realm of fine art had the capacity to effect a powerful scopic revolution by rejecting their status as, at worst, vilified others and grotesque objects as per white slaveholding iconography or, at best, as inadmissible proofs or bodies of evidence within a white abolitionist imaginary. Circulating as psychologically complex individuals within "works of art" rather than as flattened archetypes confined solely to political propaganda, aesthetic renderings of black women and men promised to augur a sea change in dominant modes of perception. Working to inspire sublime awe among white audiences on the one hand, on the other, these images celebrating black subjects as role models functioned as touchstones for emulation among African American viewers. As a self-emancipated individual who was, at least in his early days as an anti-slavery lecturer, "called upon to expose even my stripes" in the repeated demand for an exhibition of his scars to satiate white audience expectations regarding black bodies as proof, Douglass's visual archive celebrates no such sensationalist imagings of victimization. ${ }^{3 \circ}$ Instead, he relies on an emotive use of a traumatized yet defiant facial expression to ensure that psychological questions regarding the "look" of a "fugitive slave" took precedence over corporeal realities. He marshalled a whole repertoire of strategies of self-stylization, performance and representation not only within his writings but across his visual archive to ensure that his likenesses took the form not of advertisements, entries in the "chattel record" or an abolitionist "iron argument," but of the "work of art" steeped within European and European American art-historical traditions, and according to which, as Marcy Pointon describes, the portrait "should aim to represent body and soul, or physical and mental presence." ${ }^{31}$ Celebrating the transformative effects and reformist possibilities of fine art by emphasizing that " $[\mathrm{t}]$ he world has no sight more pleasant and hopeful, either for the child, or for the race, than one of these little ones in rapt contemplation of a pure work of art," Douglass foregrounded the importance of exposure to a "physical and mental presence" by insisting that " $[t]$ he process is one of self-revelation,

29 Douglass chose to subtitle My Bondage and My Freedom as "Part I - Life as a Slave. Part II - Life as a Freeman."

${ }^{30}$ Frederick Douglass, Life and Times of Frederick Douglass, Written By Himself. His Early Life as a Slave, His Escape From Bondage, And His Complete History to the Present Time, intro. George L. Ruffin (Boston: De Wolf \& Co., I 892), 620.

${ }^{31}$ Pointon, "Slavery and the Possibilities of Portraiture," 42. As regards my further discussion of the importance of the role played by white British abolitionist Granville Sharp's conception of "iron arguments," see my article " 'Iron Arguments': Spectacle, Rhetoric and the Slave Body in New England and British Antislavery Oratory," European Journal of American Culture, 26, I (2007), 57-78. 
a comparison of the pure forms of beauty and excellence without, with those which are within." ${ }_{32}$

\section{FUGITIVE PORTRAITS: IN PRACTICE}

"This is strong language. For the sake of my people I would to God it were extravagantly strong," Douglass declared in a speech he addressed to the American and Foreign Antislavery Society in New York in I 853, admitting, however, that "I cannot speak as I feel on this subject. My language though never so bitter is less bitter than my experience. At best my poor speech is to the facts in the case but the shadow to the substance." 33 Offering hard-hitting testament to his lifelong exposure to a state of physical and psychological as well as existential fugitivity, Douglass remained unequivocal regarding his sense of the vast chasm that separated his autobiographical experiences and any attempt to represent his lived realities in written or oratorical language. As his life and works reveals, his recitation of a brutal array of atrocities, however graphically narrated - his exposure to "a very severe whipping, cutting my back causing the blood to run, and raising ridges on my flesh as large as my little finger," for example - always left him with a crushing sense of textual failure. Of the "terrible spectacle" of his Aunt Hester, who had been whipped "till she was literally covered with blood," he sadly conceded, "I wish I could commit to paper the feelings with which I beheld it." 34 In addition to his deliberate adoption of an unconcilatory oratorical and prose style by which he continued his lifelong fight to come to grips with the psychological and emotional as well as physical realities of lives lived as a fugitive slave, he repeatedly turned to the visual mode in general and to "fugitive" portraiture in particular as an especially powerful and revisionist political tool assuming centre stage within his protest aesthetic and abolitionist arsenal. Working to create an alternative visual archive, Douglass operated under the conviction that if he succeeded in creating portraits according to his theory of self-imaging he would be able substitute "shadows" for "substances" regarding the realities of lives lived in slavery and freedom and thereby render a spoken or written use of language redundant. "If our dark cheek could reveal our feelings, words would be unnecessary to the beholder," he repeatedly maintained. ${ }^{35}$

${ }^{32}$ Frederick Douglass, "Pictures and Progress," 460.

${ }^{33}$ Frederick Douglass, "Appendix," in anon., The Thirteenth Annual Report of the American and Foreign Antislavery Society Presented at New York May II I853 (New York: Published by the American and Foreign Antislavery Society, I853), I 83.

${ }^{34}$ Frederick Douglass, Narrative of the Life of Frederick Douglass (Boston: Anti-slavery Office, I 845), 58, 6.

35 Douglass, "A Tribute for the Negro," 382. 


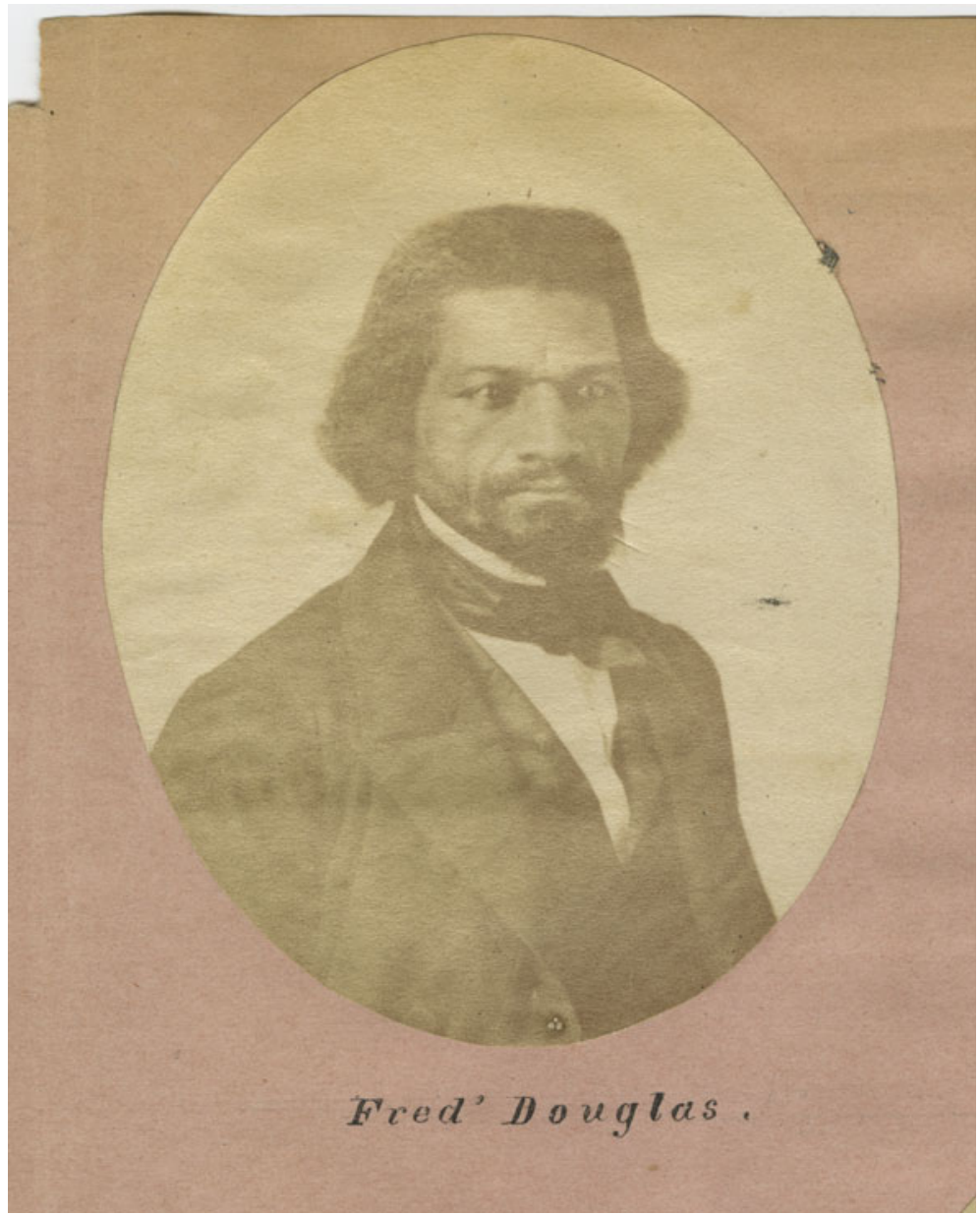

Figure 3. Anon., Frederick Douglass (n.d.). Courtesy of William L. Clements Library, University of Michigan.

Among Douglass's over I60 surviving photographic likenesses - the excavation of which was the result of a recently completed collaborative research project - are two under-discussed yet hard-hitting early examples that are especially revealing regarding his radical strategies of self-visualization: one is a sixth-plate daguerreotype, created by an anonymous photographer circa I 850 , which is a copy of an I 847 portrait, held in the National Portrait Gallery, Smithsonian Institute; the other a scrapbook version of a missing daguerreotype taken by an unidentified artist nearly a decade later in I 857 and purchased by the University of Michigan Clements Library from a New York dealer in the r 990 os (Figures 3 and 4). Signifying as a calling card 


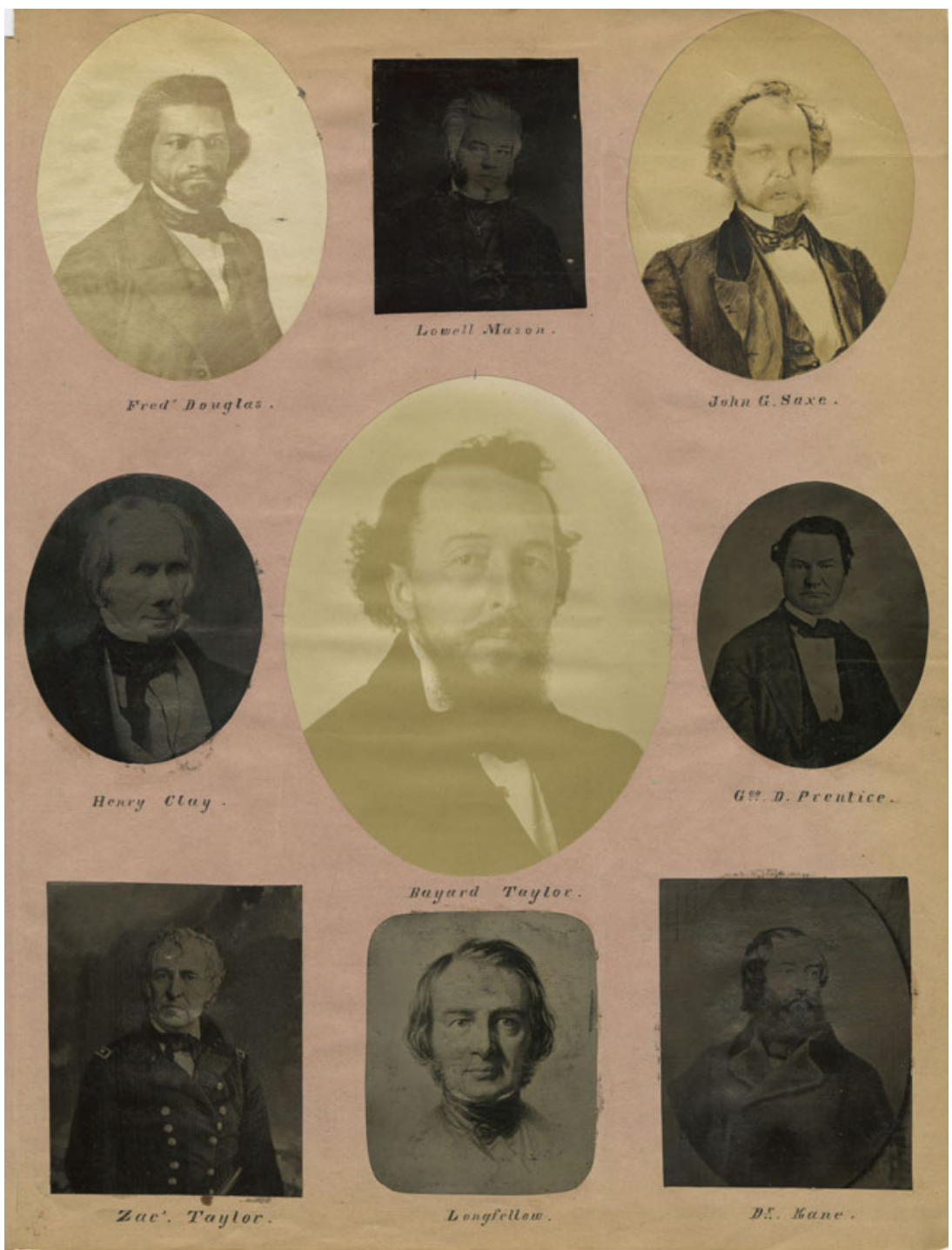

FIGURE 4. Anon., scrapbook page. Courtesy of William L. Clements Library, University of Michigan.

to black radical activism, the I 850 sixth-plate copy of an I 847 daguerreotyped portrait is directly contemporaneous with Armistead's drawing and, as such, constitutes an unequivocal testimonial regarding Douglass's determination to visualize back to grotesque portrayals of his physiognomy in particular and of enslaved and freed black women and men more generally. Posing as the quintessential "face of the fugitive slave," Douglass dominates the gilt- 
edged frame in which formal resonances with elite European painting traditions are inadmissible. His deliberate exclusion of symbolic properties for example a table, chairs, books, carpet and any other form of decorative embellishment - works in conjunction with his blank backdrop and dramatic use of lighting to illuminate rather than obscure each line on his physiognomy and render his viewers no choice but to focus solely upon his traumatized and traumatizing expression. Close examination of this work not only reveals the etched lines on his face but the cross-shaped scar on his forehead, both tellingly missing from Armistead's cleaned up and censorious reimaging of Douglass's smoothed skin. According to Frederick Douglass's son, Lewis Douglass, writing to his father decades later on 9 June 1865 from Ferry Neck in St Michael's, Maryland, the rural location in which he had lived for the vast majority of his life as an enslaved man, it was his physical wounds alone and not his exalted masculine beauty, as problematically feted in white abolitionist circles - that rendered his freed self recognizable to his family. "Your cousin Tom Bailey called on me," Lewis reports, noting, "I showed him your photograph. He remembered the scar over your nose." ${ }_{36}$

At the same time that Douglass relied on cutting-edge daguerrean technology to begin to do justice to his physical markers of identity otherwise imaged out of white dominant representations, he also worked with its technological accuracies to expose the complexities of his seemingly full frontal gaze. Any close examination of the daguerreotype's intricacy reveals a remote rather than direct expression in Douglass's eyes that confirms his adoption of a self-consciously heroic pose as he sought to look not at but through his viewers and therefore beyond their world view into an imagined future. Dramatically to the fore in this portrait is his self-conscious determination to use his wounded face not only as a touchstone for exemplary masculine beauty - as the classical symmetry of his physiognomy alone confirms the lie of white racist scientific, naturalist and philosophical associations of black faces and bodies with ugliness - but as a catalyst to his reformist vision. Foregrounding across his portraits his philosophical conviction that the "picture is a power," he sought to defy the socially determinist realities of a scopic terrain in which black subjects were reduced to objects. ${ }^{37}$ Engaged in a powerful reversal of this dehumanizing process, he provides visual confirmation of his determination to circulate not only as a "work of art," an appropriate subject of fine-art portraiture, but as a physical and spiritual

${ }^{36}$ Lewis Douglass, "Letter to Frederick Douglass," 9 June I 865, Ferry Neck in St Michael's, Maryland, Frederick Douglass Correspondence, Box 28, Folder 5, n.p., held in the Frederick Douglass Collection, Manuscripts and Rare Books, Moorland Spingarn Research Center, Howard University.

37 Frederick Douglass, "Pictures and Progress," 460. 
embodiment of the "face of the fugitive slave" and, as such, as a figure for black resistance. Constituting bold declarations of artistic authority, his strategies of self-imaging and self-imagining here and across his archive vouchsafe his deliberate assumption of the role of the "painter." Douglass sought "to give form and expression to facts and appeal to the mental experience of all for the fidelity of my pictures." 38

Regardless of its very different survival as a paper copy pasted into a scrapbook and about which as yet very little can be confirmed regarding its owner or date of construction, the later portrait created in circa i 857 may well have lost its gilt frame, and therefore its direct associations with fine-art portraiture, but it remains an illuminating image regarding Douglass's preference for performative stagings of his physiognomy. No longer making any attempt to look directly at the viewer as he rejects any pretensions towards courting their sympathy or even empathy, he yet again signals his autonomy by adopting the explicit gaze of the heroic revolutionary intent on imaging an alternative social, political and moral future. As an exceptional icon of black masculinity, the success of his cultivation of mythological associations for his own face and body can immediately be measured in his appearance as the sole African American on a scrapbook page in which the owner otherwise chose only to commemorate white historical and cultural icons of the age. In a unique historical artefact, Douglass takes the lead by appearing as the first portrait on a page distinguished by photographic, engraved and drawn likenesses of numerous white American men, including composer Lowell Mason; poets John Saxe, Bayard Taylor and Henry Longfellow; politician Henry Clay; editor George Prentice; US President Zachary Taylor; and leading medical professional Elisha Kane (see Figure 4). Regardless of their formal and thematic differences, these early portraits remain characteristic of Douglass's vast photographic and fine-art archive more generally in which a tortured and torturing facial expression assumes centre stage to the exclusion of all else as he retains a commitment to cultivating the "face of the fugitive slave" in portraiture as the quintessential medium in which to denounce not only the "fact" but the "spirit of slavery." 39

As the "most photographed nineteenth-century American," black or white, and a historical figure now recognized for exerting control over innovative technologies in a bid to stage his visual resistance to the racist misrepresentations of his face and body in fine art and popular culture, Douglass's circulation within photographic images has been the subject of intense debate over

${ }^{8}$ See Douglass, "Lecture on Pictures [title varies]."

39 Douglass, Life and Times of Frederick Douglass, 277. 
the last decade. ${ }^{\circ}$ This critical emphasis has been to the neglect, however, of the frontispieces and interior images which variously appear within Narrative of the Life, My Bondage and My Freedom and Life and Times and which are revealing not only aesthetically, but in light of Douglass's own responses. He has left incisive commentaries that serve as illuminating guides for researchers. With the exception of the pioneering scholarly work undertaken by Fionnghuala Sweeney, to date scant attention has been paid to Douglass's fury regarding the engraved frontispiece that accompanies the first Dublin edition of his Narrative and which prompted his categorical denunciation in a letter to his publisher, Richard Webb. "You asked my opinion of the portrait," he writes, stating,

I gave it, and still adhere to it, - though I hope not without due deference to yourself, and those who think with you. That the picture don't suit is no fault of yours - or loss of yours. - I am displeased with it not because I wish to be, but because I can't help it. I am cirtain $[s i c]$ the engraving is not as good, as the original portrait. I don't like it, and I have said without heat or thunder. ${ }^{41}$

Douglass's dislike of this grotesque distortion of his "original portrait" - the location and identification of which remains the subject of ongoing collaborative research by myself, John Stauffer and Zoe Trodd for our forthcoming volume Picturing Frederick Douglass - most likely derives from its heightened formal associations with white racist caricature. According to this artist's

$4^{\circ}$ See Bernier, Stauffer and Trodd, Picturing Frederick Douglass. A selected list of additional recent scholarship on Douglass and photography includes not only my articles and the co-edited (with Bill E. Lawson) African American Review special issue, Imaging Frederick Douglass, but also the following: Sarah Blackwood, "Fugitive Obscura: Runaway Slave Portraiture and Early Photographic Technology," American Literature, 8 I, I (March 2009), 93-I25; Marcy Dinius, The Camera and the Press: American Visual and Print Culture in the Age of the Daguerreotype (Philadelphia: University of Pennsylvania Press, 2012); Julia Faisst, Cultures of Emancipation: Photography, Race, and Modern American Literature (Heidelberg: Universitätsverlag, 2012); Sean Meehan, Mediating American Autobiography: Photography in Emerson, Thoreau, Douglass, and Whitman (Columbia: University of Missouri Press, 2008); Richard A. Powell, Cutting a Figure: Fashioning Black Portraiture (Chicago: The University of Chicago Press, 2009); Fionnghuala Sweeney, "Visual Culture and Fictive Technique in Frederick Douglass's The Heroic Slave," Slavery and Abolition, 33, 2 (2012), 305-20; Maurice O. Wallace and Shawn Michelle Smith, eds., Pictures and Progress: Early Photography and the Making of African American Identity (Durham, NC: Duke University Press, 2012); Donna M. Wells, "Frederick Douglass and Photography," available online at www.huarchivesnet.howard. edu/ooozhuarnet/freddoug.htm, accessed Jan. 2014.

${ }^{41}$ Frederick Douglass, "Letter to Richard D. Webb," Jan. I 846, repr. in The Frederick Douglass Papers, Series Three: Correspondence, Volume I, I842-I852, ed. John R. McKivigan (New Haven: Yale University Press, 2009), 74. For a further discussion see Fionnghuala Sweeney, Frederick Douglass and the Atlantic World (Liverpool: Liverpool University Press, 2007). 
vision, Douglass's physiognomy comes to life with a radically darkened skin tone and exaggerated facial features, as well as a hint of a smile that risks reinforcing Armistead's later troubling association of the "face of the fugitive slave" with amiability..$^{42}$ In the hands of this as yet unidentified engraver, while he does not appear as per an array of widespread strategies characterizing black images that were dominant throughout the period and which included the competing circulation of black subjects as embodiments of barbarous villainy - as per Nathaniel Turner in white American author Samuel Warner's dystopian scene of black revolution - or as romanticized archetypes à la David Walker's mythologized self-construction, as sensationalist spectacles according to Henry Box Brown's visually staged moment of liberation, as radical crossdressers as per Ellen Crafts, or even as weapon-wielding militants such as Harriet Tubman, Douglass is nonetheless configured within a white dominant imaginary as the "face" not of the "fugitive slave" but of the quintessential "slave."43 As Julia Sun-Joo Lee has recently shown, Douglass was in exalted company regarding his virulent opposition to this engraving. As early as 17 March I 848, Charles Dickens jubilantly wrote to actor W. C. Macready, "Here is Frederick Douglass," only to admit to an act of wilful defacement: "There was such a hideous and abominable portrait of him in the book, that I have torn it out, fearing it might set you, by anticipation, against the narrative." 44 Writ large in Dickens's horror is the reason for Douglass's protest against the devastating effects generated not only by his own stereotypically rendered portraits but also by the mass of black caricatures flooding the visual arena on both sides of the Atlantic: badly drawn portraits purporting to a basis in fact had the potential to wreak irreversible damage not only by casting the authority of their accompanying written narratives into doubt but also by reducing black subjects to passive ciphers, to "shadows" rather than actively empowered individuals or "substances."

${ }^{42}$ For online access to the frontispiece portrait Douglass despised see http://imagesonline.bl. uk/index.php?service $=$ search\&action $=$ do_quick_search\&language $=$ en\&q $=\% 2313767$.

43 See the frontispieces to the following: Samuel Warner, Horrid Massacre in Virginia, woodcut, illus. in Authentic and Impartial Narrative of the Tragical Scene which was witnessed in Southampton County (New York: Warner West, I 83 I); David Walker, Walker's Appeal in Four Articles (Boston: David Walker I 830); Henry Box Brown, Narrative of the Life of Henry Box Brown (Manchester: Lee \& Glynn, 185 I); William Craft, Running a Thousand Miles for Freedom (London: William Tweedie, I 860); Sarah H. Bradford, Scenes from the Life of Harriet Tubman (Auburn: W. J. Moses, I 869).

${ }^{44}$ Graham Storey and Kenneth Fielding, eds., The Pilgrim Edition of the Letters of Charles Dickens, Volume V, I847-I848 (Oxford, Clarendon Press, I981), 263; Julia Sun-Joo Lee, The American Slave Narrative and the Victorian Novel (New York: Oxford University Press, 2012). 
A decade later, in powerful vindication of his determination to create not only a black message in a black envelope vis-ád-vis his written autobiography but also a black image in a black frame regarding his visual portrait, at the same time that Douglass secured a letter of introduction for My Bondage and My Freedom from African American radical philosopher and activist James McCune Smith, he stage-managed white engraver John C. Buttre's frontispiece likeness (Figure 5).45 In contrast to the Dublin edition of his Narrative, in which he appears as an absent presence and in which his physiognomy was excessively darkened, his facial features exaggerated and his torso barely delineated, he assumes the signifying power of a present absence in My Bondage and My Freedom. In dramatic contrast to the frontispieces accompanying both the US and Irish editions of his Narrative, Buttre's meticulous rendering of his half-drawn yet excessively detailed representation of Douglass's physiognomy does powerful justice to his determination to accentuate an interiorized expression over and above material realities in a bid to convey the "face of the fugitive slave" by signalling the "inner" via the "outer man." ${ }^{6} 6$ In yet another radical departure from staple features of the frontispieces accompanying earlier editions of his autobiography, Buttre's decision to delineate Douglass's upper body in detail generates powerful visual drama. Carefully etching in Douglass's clenched fists, Buttre's technique of foregrounding the developed musculature of his hands succeeds in bolstering his militancy by alluding to his previous life as a physical labourer as contained within his present life as an anti-slavery reformer. ${ }^{47}$ While John W. Blassingame emphasizes that the "Narrative and Bondage and Freedom differ as profoundly as the daguerreotypes adorning their frontispieces," it may be argued that, at the same time that Douglass's literary use of language remained as forceful, hard-hitting, incendiary and aesthetically experimental, his stage management of his daguerreotyped images revealed his formal and thematic differences across these works. ${ }^{48}$ In contrast to the ambiguities surrounding the frontispiece to his Narrative, which Douglass himself described

${ }^{45}$ Here I am riffing off John Sekora's discussion of a "black message in a white envelope" in his seminal article "Black Message/White Envelope: Genre, Authenticity, and Authority in the Antebellum Slave Narrative," Callaloo, 32 (1987), 482-5 1 5.

${ }^{46}$ Frederick Douglass, "Pictures and Progress," 455.

47 See John Stauffer, The Black Hearts of Men: Radical Abolitionists and the Transformation of Race (Cambridge, MA: Harvard University Press, 2004); Zoe Trodd, "The After-Image: Frederick Douglass in Visual Culture," in Celeste-Marie Bernier and Hannah Durkin, eds., Visualising Slavery: Art across the African Diaspora (Liverpool: Liverpool University Press, forthcoming 2016).

${ }^{48}$ John W. Blassingame, "Introduction," in The Frederick Douglass Papers, Series Two, Autobiographical Writings: My Bondage and My Freedom, ed. John W. Blassingame, John R. McKivigan and Peter P. Hinks (New Haven: Yale University Press, 2003), 7-18. 


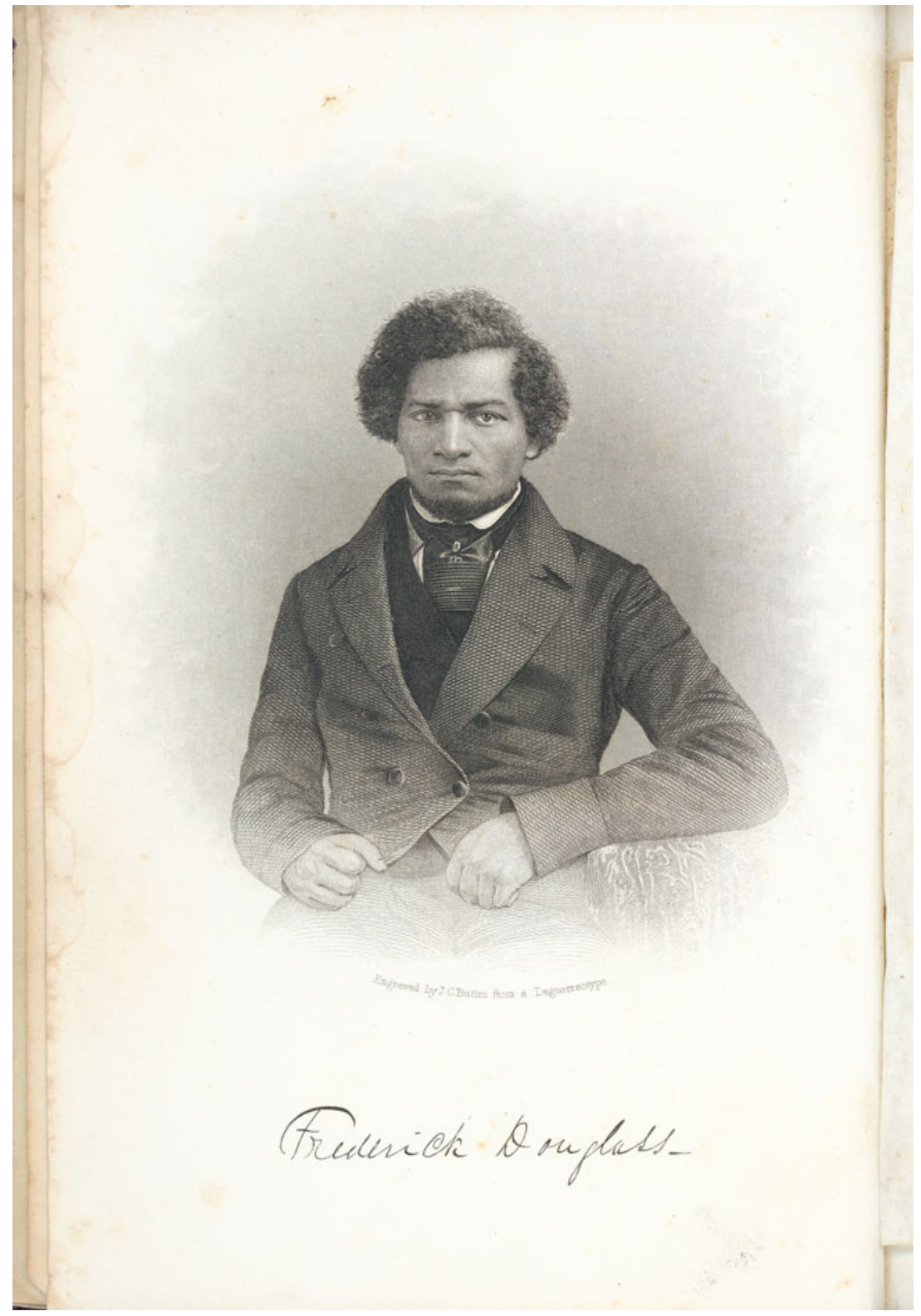

Figure 5. John Chester Buttre, Frontispiece engraving of Frederick Douglass, in Frederick Douglass, My Bondage and My Freedom (New York: Miller, Orton \& Mulligan, I 855). Courtesy of Documenting the American South, University of North Carolina.

as executed from an "original portrait," about which little is known, he renders the photographic origins of this engraving incontestable by inserting the following declaration directly beneath his portrait: "Engraved by J. C. Buttre 
from a Daguerreotype." While succeeding as an authenticatory device authorizing the accuracy of this likeness, this statement inspires ongoing research into the location of this daguerreotype, which investigations to date would suggest is no longer extant.

The frontispiece likeness to My Bondage and My Freedom in which Douglass inhabits the "face of the fugitive slave" by no means represents the sum total of the visual apparatus accompanying this work. He also includes two interior composite vignettes variously attesting not to his personal experiences of "My Bondage" and "My Freedom" but to generalized depictions of "Life as a Slave" and "Life as a Freeman." To date, these have been the subject of no scholarly investigation. Executed by white Irish engraver, Nathaniel Orr, neither of these works includes any visual representation of Douglass himself (Figures 6 and 7). Rather, the generic content of both works offers visual confirmation that Douglass most likely commissioned Orr to dramatize scenes not from his individualized narrative but from the life of a representative and archetypal "fugitive slave" as lived in "bondage" and "freedom." While no records remain to shed light on his rationale for their inclusion, I would argue that Douglass most likely inserted these images into a publication over which he had full control as a visual shorthand for his conceptualization of his narrative as simultaneously both a private testimonial and a public call to arms. These generic images summarizing scenes from slavery appear in slippery relation to the individualized drama of his frontispiece portrait by accentuating the representative significance of his cultivation of a fugitive rather than fixed autobiographical persona, and even personae, yet further.

The first image documents the generic "life" of a "slave" by including the following scenes that formed a visual staple within the abolitionist arsenal: a half-naked black man pursued by a white slaveholder and bloodhound as a visual embodiment of the runaway-slave archetype; a white slave trader auctioning off the downcast figure of an enslaved woman as an iconic signifier of black female martyrdom, black men working in the cotton fields as archetypal imaginings of black labouring bodies, caricatured black men clothed in rags and forced to dance before white audiences as per minstrelsy archetypes, and lastly passive black families seated in front of a slave cabin in seeming adherence to the "loyal slave" mythology of white abolitionist propaganda as they remain nonviolent despite the threat presented by a white vigilante group appearing close by and the atrocities enacted in the scenes immediately above. ${ }^{49}$ By comparison, Orr's similarly hard-hitting composite vignettes dramatizing the representative "life" of a "freeman" bear witness to Douglass's 


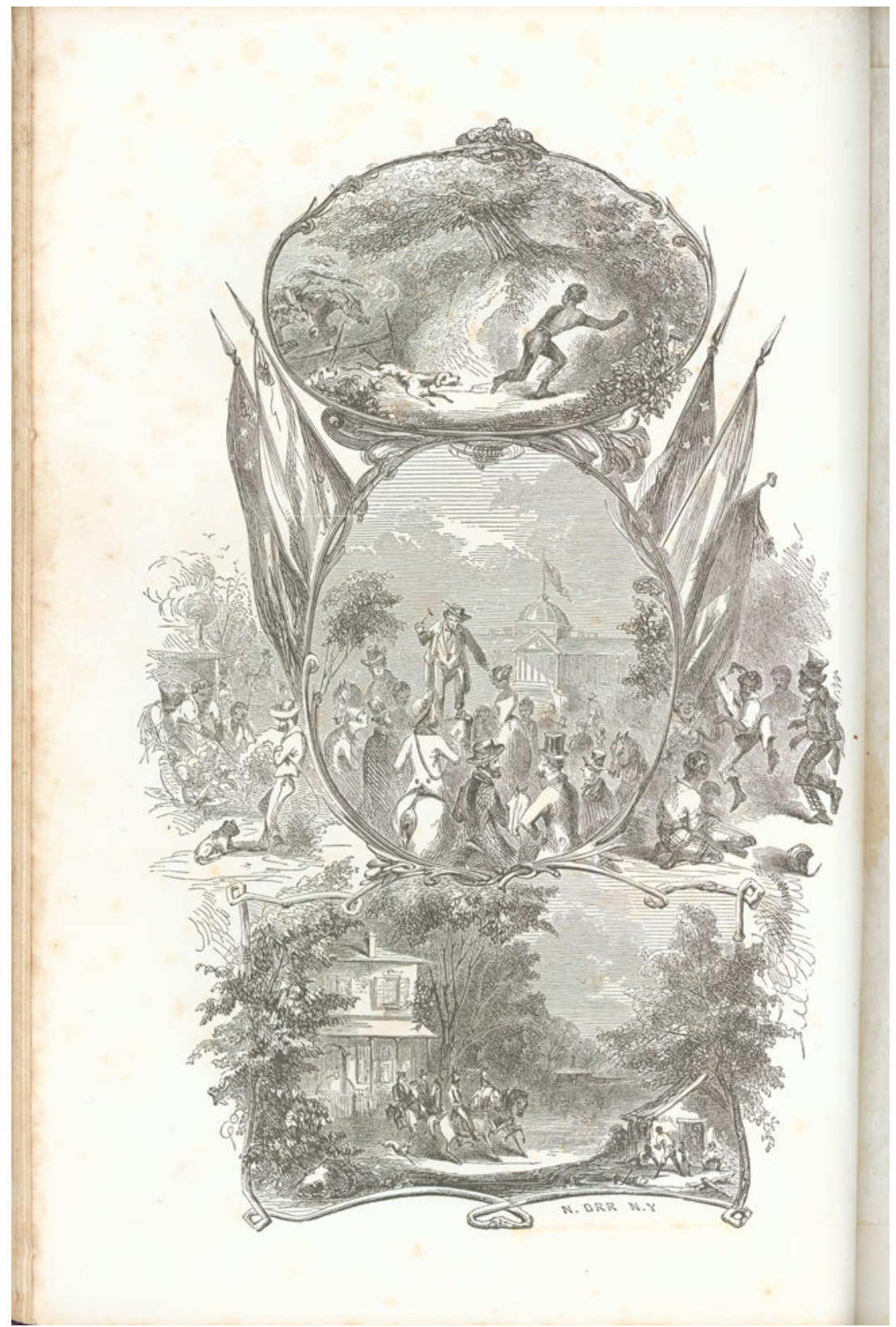

Figure 6. Nathaniel Orr, "Life as a Slave," in Frederick Douglass, My Bondage and My Freedom, 33. Courtesy of Documenting the American South, University of North Carolina. 


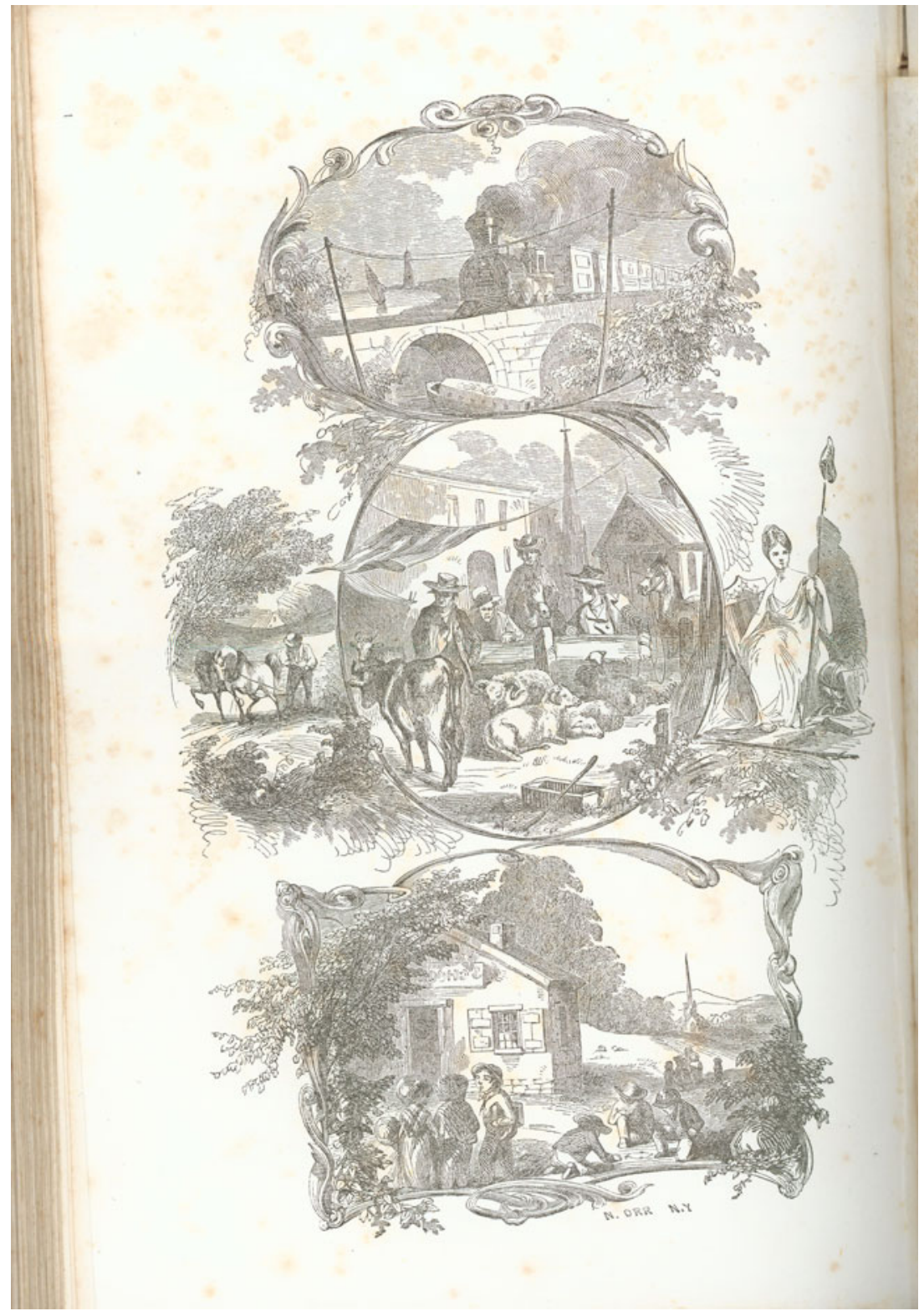

Figure 7. Nathaniel Orr, "Life as a Freeman," in Frederick Douglass, My Bondage and My Freedom, 334. Courtesy of Documenting the American South, University of North Carolina.

protest against the archetypal life of the "freeman" in a virulent rejection of a hagiographic vision of a utopian North. Across this multi-panel work, Orr exposes racist inequalities in the fact that black women, men and children 
are variously excluded from scenes of modernity and civilization (a steam train crossing a bridge and a boat sailing down the river); from agricultural pursuits (as farming scenes show only white figures engaged in working with animals); from educational opportunities (as white children are portrayed playing before a school house); and, most damningly of all, from freedom itself on the grounds that liberty is allegorically embodied by a white woman and is therefore the preserve of whites only. ${ }^{\circ \circ}$ At the same time that he adopted experimental literary strategies by which to defy the widespread circulation of a mass of black lives prepackaged and oversimplified slave narratives, then, Douglass opted for a slippery relationship between images in an equally selfreflexive visual apparatus. Working to reimage as well as reimagine the many faces of many fugitive slaves, he sought to hold in balance an unequivocal dramatization of his own life with a no less hard-hitting exposure of the widespread injustices confronting black political, historical, social and cultural lives as lived in an antebellum and postbellum US more generally.

For Douglass, the dramatic tensions at work within the visual apparatus accompanying his Narrative of the Life and My Bondage and My Freedom, and as similarly to the fore in the experimental literary devices he employed across both works, were to experience a powerful resurgence in a post-emancipation era. Even a cursory investigation reveals that by far the most virulent controversies besetting his textual archive concern the illustrations accompanying the I $88 \mathrm{I}$ edition of his Life and Times. While Douglass registered no opposition to the individualized portrait meticulously engraved by white artist Augustus Robin from a likeness created by white photographer Charles Warren, he saved all his ire for the seventeen generic interior woodcuts which he vociferously condemned. Writing a letter to his editor, Sylvester M. Betts, at the Park Publishing Company, on 30 October I $88 \mathrm{I}$, he was unequivocal: "I am no more reconciled than ever to the publication of my life with the illustrations, and I ask and insist, as I have a right to do, that an edition of the book shall be published without illustrations, for Northern circulation," Douglass declares, emphasizing,

I beg to remind you, that in the contract made with me, for the publication of the book, you say nothing about illustrations; you only bind yourself to publish the book "on good white paper," with a steel engraving of the author. This contract does not permit you to load the book with all manner of coarse and shocking wood cuts, such as may be found in the news papers of the day.

Vouchsafing his authority yet further, Douglass threatened Betts with legal action by insisting, "you have gone outside the contract, taken the matter in 
your own hands, and, I hold, have marred and spoiled my work entirely." "I have no pleasure whatever in the book, and shall not while the engravings remain," he concedes, speculating, "I think I have ground for appealing to the law under the contract, and getting an injunction against your publishing the book in its present shape." 5 - Writing only a few months later on 28 January i 882 , however, Douglass confirmed his resignation, unabated fury notwithstanding, by informing Betts, "I have given up all opposition to the illustrations, and am silent about typographical errors, and submit to the caracature $[s i c]$ of my own face." ${ }_{52}$ Warring against the enduring iconographic stranglehold exerted by a white-supremacist lens, Douglass's opposition to the "caracature of my own face" testifies to his ongoing commitment to commissioning empowered and empowering images that would inspire his audiences to philosophical contemplation by remaining impervious to reductive explication, political objectification or didactic moralizing. Adding insult to injury, the publisher chose to compound these injustices yet further by offsetting Douglass's appearances in disfigured and grotesque woodcuts with a series of individualized portraits of John Brown, William Lloyd Garrison, Wendell Phillips, Charles Sumner and Abraham Lincoln. As Douglass knew only too well, these delicately drawn works celebrating white political figures performed the unforgivable work of writing black radical abolitionism out of history while imaging "the face of the fugitive slave" out of iconographic no less than political and art-historical existence.

As a close examination of the iconography included not only within Douglass's bodies of work but also within works created by a number of formerly enslaved and self-emancipated authors and artists confirms, the genre of "fugitive slave portraiture" took many forms, encompassing the multifaceted representational strategies on offer within portrait frontispieces purporting to provide individualized likenesses of black subjects on the one hand and generic interior illustrations committed to rehearsing stock abolitionist tableaux on the other. Offering a vast arena for future research, the category of fugitive slave portraiture as applied not only to Douglass but to the works produced by an array of other black authors and artists speaks to the necessity not only of examining the formal and thematic components within individual images themselves but also of tracing their slippery relationships to the textual narratives in which they appear as they functioned both to reinforce but also to

${ }^{51}$ Douglass, "Letter to Sylvester Betts," 30 Oct. I 88 I; see "General Correspondence Files," the Frederick Douglass Papers, Library of Congress Special Collections, available online at www. loc.gov/collection/frederick-douglass-papers/about-this-collection, accessed Jan. 2014.

52 Douglass, "Letter to Sylvester Betts," 28 Jan. I 882; see "General Correspondence Files," the Frederick Douglass Papers, Library of Congress Special Collections, available online at www. loc.gov/collection/frederick-douglass-papers/about-this-collection, accessed Jan. 2014. 
resist literary reimaginings of their subjects' life stories. As even a brief examination reveals, the vast majority of formerly enslaved narrators, and most especially Douglass, cultivated a powerful relationship between the specificity of their individual portraits and the genericism of their interior illustrations in a bid to extend the signifying and representational possibilities for black subjectivities and thereby challenge audience assumptions. As is typically the case concerning the visual apparatus accompanying African American-authored literary works, and as is clearly at work within Douglass's textual and visual archive, both the frontispiece portraits and the interior illustrations constitute no straightforward extensions of an individual narrator's autobiography. Rather, they operate as highly mediated, constructed and complex works which generate thematic and formal tensions because of their semantically shifting relation to the authority of the texts in which they appear.

Given the important role played by white publishers and printers in controlling the editing, packaging and final appearance of black-authored narratives and images, any examination of the formal devices on offer within fine-art and photographic representations of enslaved subjects renders it of fundamental importance to take due note of Angela Rosenthal and Agnes Lugo-Ortiz's groundbreaking emphasis that the burden is upon scholars to "interrogate the sites of production and preservation of slave portraiture, the violence of their origins and their unintended paradoxes." 53 For formerly enslaved and selfemancipated authors and artists such as Douglass working to represent corporeal and spiritual experiences that remained not only textually off-limits within the objectifying confines of dominant literary paradigms but also iconographically beyond the pale according to European standardized aesthetic conventions, theirs was a commitment not only to writing but also to visualizing back. As his photographic and fine-art portraits evidence, across his visual archive Douglass sought to defy the constraints of a "black message in a white envelope" in order to create a black image within a white scopic frame. ${ }^{54}$ As one individual among many who was intent on laying the foundations for a new genre of fugitive slave portraiture, he sought to endorse the circulation of black subjects as fugitive images rather than as fixed facts. Across an array of experimental works whose signifying possibilities we are only now beginning to theorize, Douglass and countless others worked to represent black subjects as empowered "shadows" rather than as objectified "substances" in a determination to "flip the script," or more accurately "flip the image," and thereby emancipate black women, men and children from the

53 Lugo-Ortiz and Rosenthal, "Introduction," I I.

${ }^{54}$ See Sekora, "Black Message/White Envelope," 482-51 5. 
stranglehold exerted by a socially reductive and politically determinist, but above all else aesthetically annihilating, white racist visual schema.

Douglass's exposure to the nefarious forces at work within the "caracature of my own face" ultimately bears witness to the iconographic stranglehold exerted by a white racist lens which gained rather than lost momentum throughout the nineteenth century. In this regard, the controversies surrounding the whitegenerated visual apparatus of Life and Times in the i 880 of offer incontestable proof of a damning social, political and art-historical context in which Douglass's prewar theorizations still hold ground. "The European face is drawn in harmony with the highest ideas of beauty, dignity and intellect. Features regular and brow after the Websterian mold," he writes as early as I 854 , deploring the fact that " $[t]$ he negro, on the other hand, appears with features distorted, lips exaggerated, forehead depressed - and the whole expression of the countenance made to harmonize with the popular idea of negro imbecility and degradation." "Is "If the very best type of the European is always presented, I insist that justice, in all such works, demands that the very best type of the negro should also be taken," Douglass concluded. As his lifelong commitment to stage-managing and commissioning his own photographic and fine-art portraits in particular demonstrates, Douglass's resistance strategies took root from his conviction that "the very best type of the negro" was ultimately to be found in his own physiognomy as an archetype of black humanity, a realization that in and of itself was not only a liberatory call to arms but a problematic declaration that lies at the heart of ongoing research. ${ }^{56}$

\section{FUGITIVE PORTRAITURE: A THEORY AND PRACTICE}

Douglass's philosophical and aesthetic convictions operate as a powerful starting point even within twenty-first-century debates by having the potential to provide new ways of interpreting Rosenthal and Lugo-Ortiz's observation that "the ghostly enslaved subject exist within and without portraiture," as they acknowledge even of their own seminal volume that "the very focus of this collection on slave portraiture must exist as well in a liminal space of undecidability and paradox." According to Douglass's rejection of white racist overdeterminations of black physical attributes, their declaration may well be a source of hope rather than despair on the grounds that due recognition of the "undecidability and paradox" of a "fugitive slave portraiture" tradition has the potential to open up alternative spaces of ambiguity and artistry in

5s Frederick Douglass, The Claims of the Negro Ethnologically Considered (Rochester: Lee, Mann \& Co., I 854), 20-2I.

${ }_{56}$ Ibid., 21, original emphasis. 
defiance of attempts to commodify, fix, appropriate, authenticate, own, or propagandize black faces and bodies. ${ }^{57}$ Recognizing the importance of Marcia Pointon's observation of a general academic practice by which, even today, "It is customary to reproduce these frontispieces as illustrations in academic books about slavery, and to have them on the screen as PowerPoint images while a lecturer speaks, but they are very seldom discussed qua image," the onus is upon scholars to return not only to earlier black authors and artists' strategies of self-imaging in general but to Douglass's endorsement of an alternative theoretical language in particular in order to establish a new intellectual framework by which to liberate groundbreaking examinations of the formal and thematic dimensions at work within diverse forms of elite and popular black portraiture. ${ }^{8}$ Writing incisively regarding "the act of self-portraiture, its effects and uses as a fitting form of repair, reclamation, and redemption," it is no less useful for critics to revisit James Smalls's illuminating observation via the extent to which Douglass's theoretical analysis has laid the foundations for identifying a tradition of black fugitive portraiture as forcefully characterized by resistance, radicalism and reimaging in a bid to extrapolate not solely an "imaging of self" but also an imagining of multiple selves. 59 Simultaneously engaged in imaging Frederick Augustus Washington Bailey and imagining Frederick Douglass, in one life alone scholars then and now confront not only a vast visual archive but also an alternative theoretical framework in which a formerly enslaved individual interpreted the art of selfportraiture as the ultimate act of self-emancipation. As a freedom fighter turned author, orator and self-invented icon, he ultimately fought to dramatize the philosophical, existential and imaginative inner life of Frederick Augustus Washington Bailey Douglass, an invented persona and radical fiction which remained a powerful touchstone regarding his transformation of the face and body of the "American slave" into not only the "fugitive slave" but also the fugitive slave image.

To return to Frederick Douglass's protest against Wilson Armistead's portrait, a private letter he wrote on I 6 May I 846 during his abolitionist speaking tour of Britain, to Ruth Cox, a woman he erroneously identified as a missing sister named Harriet, is revealing regarding the psychological, political, artistic, social and cultural issues at stake within his conceptualization of the form and function of black portraiture. Shedding rare light on the emotional trauma and psychological tensions that lay beneath the surface of his self-consciously

57 Rosenthal and Lugo-Ortiz, "Introduction," 5.

58 Pointon, "Slavery," 56.

59 James Smalls, "African-American Portraiture: Repair, Reclamation, Redemption," Third Text, I 5, 54 (2001), 47-62, 47, original emphasis. 
crafted public images and which remained dramatically to the fore across his experimentation with an array of oratorical and writerly modes, he poignantly confides, "I got real low spirits a few days - ago - quite down at the mouth," declaring, "I felt worse than 'get out'. My under lip hung like that of a motherless colt. I looked so ugly that I hated to see myself in the glass. There was no living for me." 60 Written one year following the first publication of his Narrative and as little as four months prior to white abolitionists' purchase of his freedom, this letter provides evidence that Douglass's state of fugitivity was powerfully exacerbated at this moment: a moment in which he was simultaneously both enslaved and free in not only metaphorical, symbolic and mythological but also legally, historically and politically definitive terms. ${ }^{61}$ Shedding light on Douglass's intense dislike of Armistead's image, which he despised for its failure to represent the "face of the fugitive slave," is his powerful admission, "I looked so ugly that I hated to see myself in the glass." For Douglass, the portraits that he theorized, commissioned, stage-managed and choreographed remained heavily imbued with his determination not only to denounce physical atrocities but to betray the horrifying realities of enslaved and free subjects' exposure to a lifelong psychological wounding, a mental scarring which typically remained inexpressible in words and therefore beyond the pale of his written archive and yet which succeeded in dominating his visual archive over the decades. Scarcely a few years out of slavery, Douglass's realization that " $[\mathrm{t}]$ here was no living for me" at the moment of experiencing existential torture offers categorical confirmation of the fugitive slave portrait's importance as a "work of art" in which he fought to attest to the deathless life and lifeless death that was a state of fugitivity "indelibly marked on our living flesh." ${ }^{62}$ As talismans testifying to suffering and survival, Douglass's portraits ultimately assume heightened significance as memorials in which he sought to lay bare an afterlife in freedom as lived within the context of his ongoing exposure to the after-death of slavery. For Frederick Douglass no less than for Frederick Augustus Washington Bailey, the act and art of fugitive slave portraiture held out the possibility for self-transformation, self-invention and self-creation as he spent a lifetime warring against his stark realization that "[p]ictures come not with slavery and oppression and destitution." ${ }_{3}$

${ }^{60}$ Frederick Douglass, "Letter to Harriet," I 6 May i 846, n.p., Addition II, Box 53, Library of Congress Frederick Douglass Papers (undigitized).

${ }^{61}$ Hugh Auld, "Letter to Anna Richardson" 6 Oct. I 846. A full transcript is available online at www.gilderlehrman.org/sites/default/files/inline-pdfs/T-07484.04.pdf.

${ }^{62}$ Frederick Douglass, "To Our Oppressed Countrymen," North Star, 3 Dec. I 847.

${ }^{63}$ Frederick Douglass, I4 June 1870 , repr. in Katharine Morrison McClinton, The Chromolithographs of Louis Prang (New York: Clarkson N. Potter, Inc., I 973), 37. 